\title{
Capital structure in South Korea: a quantile regression approach
}

\author{
Bassam Fattouh*, Pasquale Scaramozzino, Laurence Harris \\ Centre for Financial and Management Studies, SOAS, University of London, Thornhaugh Street, \\ London WC1H OXG, United Kingdom
}

Received 1 September 2001; accepted 1 December 2003

\begin{abstract}
Knowledge of how South Korean firms choose their capital structures has particular value due to the country's specific corporate structure and the role of leverage in the evolution of its financial crisis of 1997 and recovery. Using a large panel for the years 1992-2001, we investigate the evolution and determinants of Korean firms' capital structure and focus on differences between firms in different quantiles of the debt-capital distribution. Conditional quantile regressions show that while variables associated with standard models of asymmetric information costs are significant throughout the distribution, there are considerable differences, including differences in sign, in their impact on firms with different degrees of leverage. Those observed nonlinearities in the determinants of capital structure are consistent with a model of capital structure that includes both costs resulting from asymmetric information and an upper bound on the debt-capital ratio.

(C) 2004 Elsevier B.V. All rights reserved.
\end{abstract}

JEL classification: G32; O53

Keywords: Capital structure; Quantile regression; South Korea

\section{Introduction}

The central question of corporate finance, 'what determines firms' choice of capital structure?', has, since the East Asian crises of 1997, acquired new significance in the

* Corresponding author. Tel.: +44 20 78984053; fax: +44 2078984089.

E-mail address: bf11@soas.ac.uk (B. Fattouh). 
context of developing economies. The debt ratios of South Korean firms in particular have been a focus for attention since the high leverage ratios of Korean firms are believed to have had a role in the evolution of that country's crisis of 1997.

Apart from debt's properties as a tax shield, costs arising from information asymmetries, including agency costs, can explain the firm's choice of debt-equity ratio (Jensen and Meckling, 1976; Myers and Majluf, 1984; Harris and Raviv, 1991). Empirical studies have demonstrated the robustness of a standard model of such cost variables as determinants of the firms' capital structure. Titman and Wessels (1988) and Rajan and Zingales (1995) find that variables acting as proxies for costs arising from asymmetric information - a firm's size, profitability, asset tangibility, and growth prospects - have a significant relationship with capital structure in US data and other advanced industrialized countries. A recent study of 10 developing countries, using the IFC database to estimate that standard model, shows that firms' debt-equity ratios there, too, can be explained by those variables. However, the authors find persistent differences across countries, indicating that specific country factors, reflecting institutional differences, are at work (Booth et al., 2001).

The determinants of South Korean firms' capital structure warrant further study for two reasons: the possibility that South Korea's growth has rested on a special institutional structure that could distort the firms' capital structure towards high leverage; and the role of firms' leverage in the evolution of the 1997 crisis and subsequent recovery.

South Korea's growth from the 1960s to the 1990s was accompanied by state intervention in credit markets as an instrument of an active industrial policy (Chang, 1994). Although that industrial policy has been dismantled since the early 1990s, the corporate structure associated with it, especially the role and governance of chaebol, persisted. If the standard model that explains capital structure elsewhere fits Korean data for the 1990s, it would imply that such institutional features have not negated the effects of agency and other costs normally associated with asymmetric information.

High leverage characterized several East Asian economies before the region's 1997 crises and, to varying degrees, was an element contributing to the crises, especially in South Korea. While some identify high leverage as the principal factor, others locate the underlying cause of the crisis in deteriorating fundamentals with high leverage ratios having the important effect of linking fundamentals to the financial markets in a negative feedback (Lee et al., 2000; Claessens et al., 1998; Kim and Stone, 1999; Harvey and Roper, 1999; Pomerleano and Zhang, 1999; Harris, 2000).

From that perspective, high and increasing debt ratios accompanying Korean firms' growth in the 1980s and 1990s, particularly reliance on foreign debt, caused them to be highly vulnerable to deteriorating fundamentals and financial market shocks such as those of 1997. Consequently, reducing the reliance of firms on debt has been a central element of Korea's program to restructure corporate finance, corporate governance, and the financial system since 1998. In particular, measures to reduce the leverage ratios of the chaebol have been promoted and large reductions have been achieved (International Monetary Fund, 1998; Lee et al., 2000; Financial Supervisory Commission, 2002).

Knowledge of how firms choose their capital structures has particular value due to the role of leverage in the evolution of South Korea's fragility in the 1990s and the centrality the authorities and capital markets have given to debt-capital ratios in subsequent 
economic restructuring. Using a large panel for the years 1992-2001, we investigate the evolution and determinants of South Korean firms' capital structure and focus on the differences across firms in different quantiles of the debt-capital distribution. Although regression estimates find that standard asymmetric information cost variables explain South Korean firms' debt equity ratios (Lee et al., 2000), conventional techniques using conditional means of the variables do not take full account of the heterogeneity of the sample of firms. We report the results of estimating such relationships using conditional quantile regressions rather than conditional means.

We find that the evolution of the debt-capital ratio and other variables before and after the 1997 crisis differs markedly across firms according to the level of their debt-capital ratio. Our quantile regressions show that the leverage ratios of firms in different quantiles of our sample have significantly different sensitivity to the explanatory variables. Quantile regression allows us to examine the whole distribution of firms rather than a single measure of the central tendency of the capital structure distribution. Consequently, we are able to evaluate the relative importance of explanatory variables at different points of the distribution of firms' leverage. While variables associated with asymmetric information costs in the standard model are significant throughout the distribution, we find considerable differences in their impact in firms with different levels of leverage. The size of the firm and its rate of growth have a positive impact on debt at low values of the debt ratios, but a negative impact at high values of the ratios. By contrast, the proportion of net fixed assets has a relatively modest positive impact at low values of the debt ratios, but a much larger impact at medium or high values of the ratios.

Those observed nonlinearities in the determinants of capital structure are consistent with a model that includes both costs arising from asymmetric information and an upper bound on the debt-capital ratio. Since there are such nonlinearities in the relationship between firms' capital structure and its determinants, results derived from OLS estimates are less informative.

The quantile regressions confirm that throughout the distribution the variables influencing firms' choice of capital structure were similar to those in the US and other countries, and consistent with the standard asymmetric information cost regression model. They suggest that the Korean model of government industrial policy did not generate unusual financing choices throughout the listed corporate sector although institutional effects on the chaebol subsector's leverage have been found (Lee et al., 2000). Regarding the post crisis corporate restructuring, our results suggest that the Republic of Korea was correct to concentrate its reform of corporate finance on a subsector of firms, the chaebol, for, although there is no perfect match, they had the highest leverage ratios.

Our regressions provide evidence that the crisis and the post crisis reforms did change firms' choices throughout the sample, shifting the relationship between leverage and the variables that affect it. We find systematic relationships between firms' capital structure and the standard proxies for asymmetric information costs and tax shield; from 1992 to 1997 time dummies had almost no significant effect on the relation in individual quantiles, but the 1998 time dummy had a significant effect in the majority of quantiles and was significant across almost all quantiles in 1999, 2000, and 2001. These findings are consistent with the notion that the industrial and financial restructuring policies the Republic of Korea adopted after the 1997 crisis, in conjunction with other time-varying 


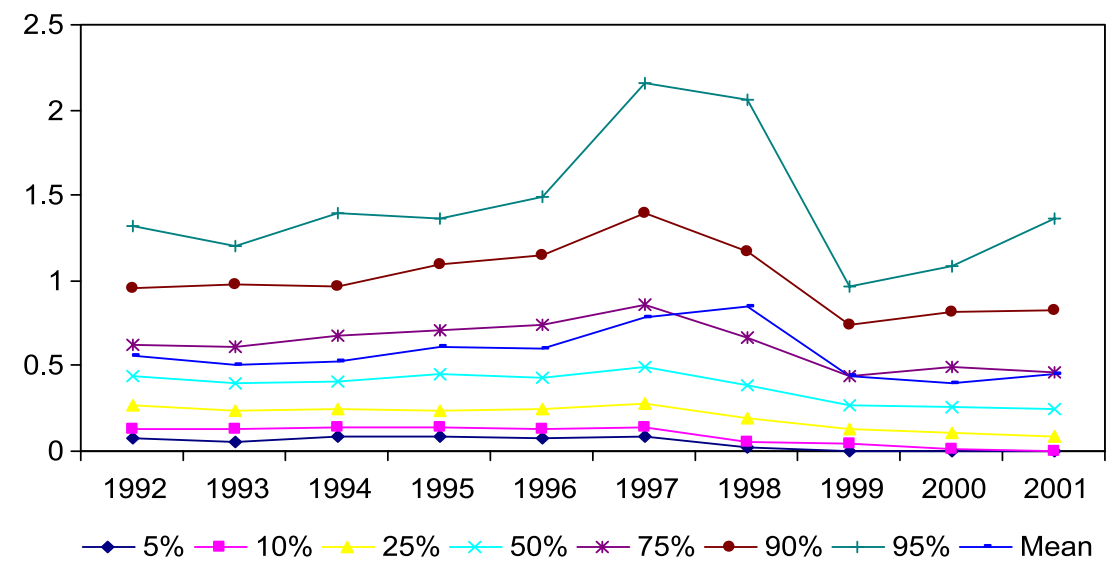

Fig. 1. Evolution of short-term debt to capital ratio, 1992-2001.

factors such as the credit crunch experienced in 1998 as a result of the financial crisis, did achieve a widespread shift in the relationship between firms' financing and costs arising from asymmetric information.

The paper is organized as follows. Section 2 examines the debt structure of Korean firms during the period 1992-2001. Section 3 presents a model of capital structure that allows for nonlinearities in the determinants of capital structure. Sections 4 and 5 outline the empirical methodology and data while Section 6 presents the quantile regression results. Section 7 summarizes the findings and concludes.

\section{Capital structure in South Korea}

Heavy reliance on debt finance, mainly from the domestic banking system, was a major feature of the 'Asian miracle' and is reflected in the high leverage of East Asian firms. During the period 1988-1996, Korean firms had the highest leverage and the highest growth of leverage ratios as measured by the mean of the leverage ratios of listed Korean firms (Claessens et al., 1998). However, there was large variation across Korean firms in the evolution and the level of their leverage. As such, it may not be accurate to draw conclusions based on mean values. In order to explore the capital structure of Korean firms, we examine the entire distribution of debt to capital ratio. The data used in this section consist of selected variables from the balance sheets of Korean firms listed on the Korean Stock Exchange over the period 1992-2001. ${ }^{1}$

Fig. 1 depicts the short-term debt-to-capital ratio over the period 1992-2001 at various quantiles of the distribution. ${ }^{2}$ As can be seen from this figure, the mean short-term debt-to-

\footnotetext{
1 The source of the data is Thomson Datastream. Precise definitions of these firm-related variables are given in Appendix.

2 The choice of debt-to-capital ratio instead of debt-to-equity ratio is driven by the fact that many firms in our sample have small or even negative equity. This is especially true during 1997-1998 when equity values fell dramatically as a result of the crisis, inflating the debt to equity ratios.
} 


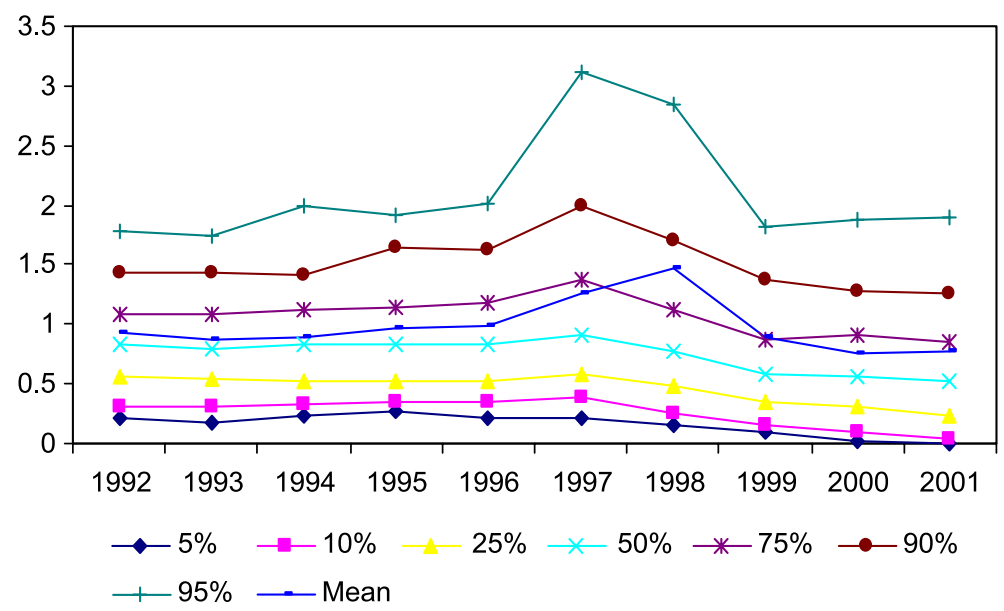

Fig. 2. Evolution of total debt to capital ratio, 1992-2001.

capital ratio increased sharply prior to the crisis; however, the increase in the mean has been driven mainly by the upper quantiles of the distribution where firms experienced very steep increases in their short debt to capital ratios, especially in 1997. In fact, Fig. 1 shows that very little increase in the short debt-to-capital ratio occurred at the lower quantiles of the distribution. For example, for firms in the 5th quantile, the debt-to-capital ratio in 1997 was almost at the same level as that of 1992. By comparison, the debt-to-capital ratio for the 95 th quantile increased from $132 \%$ in 1992 to $216 \%$ in 1997 . The median of the shortterm debt capital ratio is consistently below the mean, indicating that the debt to capital distribution is right skewed, and more so closer to the crisis. ${ }^{3}$ The ratio of total debt to capital (Fig. 2) shows a similar pattern. Although its mean increased, especially during the period 1995-1997, this rise was mainly attributable to the steep increases in the ratio for the upper quantiles of the distribution.

In Table 1, we compare some firm characteristics at different quantiles of the short-term debt to capital distribution. ${ }^{4}$ First, regarding size, firms between the 90th and 95th quantiles are on average the largest as measured either by total sales or total assets followed by firms between the 75 th and 90 th quantiles. ${ }^{5}$ Regarding profitability, Table 1 shows that earnings ratio tends to decline as we move up the distribution of short-term leverage. On average, highly leveraged firms, especially those located at the upper $25 \%$ of

\footnotetext{
${ }^{3}$ Note that in Figs. 1 and 2, the distance between the quantiles widened in the upper segments of the distribution while became narrower in the lower segments of the distribution. This indicates that the distribution has become more skewed towards high leverage over the sample period. This could have led to heightened financial fragility (see Bernanke and Campbell, 1988).

${ }^{4}$ We report the results for 1997 only, but the same pattern is observed in other years.

5 We listed the firms in the 90th quantile and then examined whether these firms are identified with the 30 largest chaebol listed by Lee et al., (2000). We find that around 55\% of firms in the 90th quantiles can be identified with chaebol.
} 
Table 1

Firm characteristics at different parts of the short-term to capital distribution

\begin{tabular}{lccccccccc}
\hline & $<5 \%$ & $5-10 \%$ & $10-25 \%$ & $25-50 \%$ & $50-75 \%$ & $75-90 \%$ & $90-95 \%$ & $>95 \%$ & Overall mean \\
\hline SIZE1 & 277 & 130 & 676 & 509 & 737 & 1120 & 2670 & 230 & 745 \\
SIZE2 & 364 & 221 & 897 & 693 & 876 & 986 & 1380 & 351 & 790 \\
PROF & 0.057 & 0.049 & 0.051 & 0.044 & 0.034 & 0.019 & -0.011 & -0.103 & 0.03 \\
TANG & 0.320 & 0.312 & 0.297 & 0.323 & 0.332 & 0.267 & 0.279 & 0.286 & 0.308 \\
DEP & 0.036 & 0.032 & 0.033 & 0.034 & 0.028 & 0.024 & 0.025 & 0.028 & 0.03 \\
NOBS & 32 & 32 & 94 & 160 & 160 & 95 & 32 & 32 & 637 \\
\hline
\end{tabular}

SIZE1 is total sales in millions of local currency, SIZE2 is total assets in million of local currency; PROF is EBITDA divided by total assets; TANG is the ratio of net fixed assets to total assets; DEP is the ratio of depreciation expenses to total assets; and NOBS is the number of observations. The data correspond to 1997.

the distribution, have lower earnings ratios than those located at the lower or middle parts of the distribution. Finally, the table shows that the ratio of net fixed assets to total assets, an indicator of asset tangibility, is quite similar across the various quantiles. The same can be said for the ratio of depreciation to total assets, an indicator of non-debt tax shield.

Thus, examination of the distribution of data shows that before and after the crisis of 1997 there were large differences in the level and the evolution of debt structure across Korean firms. Those differences suggest that problems associated with high and rising leverage were not wide ranging before the 1997 crisis, but the heightened fragility of the minority of firms at the top end of the distribution was enough to convey bad signals to foreign investors and induce a swing to pessimism about the economy as a whole.

The heterogeneity in our sample warrants examination of the whole distribution of leverage rather than focus on a single central tendency measure. Given the heterogeneity of firms, we would expect the determinants of leverage to have a different impact depending on the firm's degree of leverage. In the next section, we present a simple model that allows for such differential effects.

\section{Determinants of capital structure}

The theoretical literature on capital structure suggests a number of reasons to account for the debt-capital ratios chosen by corporations based on the agency cost of debt and equity and other costs associated with asymmetric information (Jensen and Meckling, 1976; Myers and Majluf, 1984; Harris and Raviv, 1991).

A simple formal model of maximization of the firm's value enables us to derive the testable implication that the relationship between a firm's leverage and its determinants is nonlinear.

The objective function for the firm can be written as ${ }^{6}$ :

$$
\max V_{t}=E_{t}\left\{\sum_{s=0}^{\infty} \beta_{t+s} \Pi_{t+s}\right\}
$$

\footnotetext{
${ }^{6}$ For simplicity, and without loss of generality, the firm-specific index is omitted throughout.
} 
where $\beta_{t+s}$ is the (time-varying) discount factor and $\Pi_{t+s}$ are after-tax cash flows, defined as

$$
\begin{aligned}
\Pi_{t}= & \left(1-\tau_{t}\right)\left[p_{t} F\left(K_{t}, L_{t}\right)-w_{t} L_{t}-A\left(B_{t-1} ; \mathbf{x}_{t}\right)\right]+\tau_{t}\left(D_{t}+r_{t} B_{t-1}\right) \\
& +\left[B_{t}-\left(1+r_{t}\right) B_{t-1}\right]-p_{t}^{k} I_{t}
\end{aligned}
$$

where $K_{t}$ and $L_{t}$ are capital and labor, respectively, $B_{t}$ is the stock of debt, $p^{k}{ }_{t} I_{t}$ is nominal investment, $p_{t}$ is output price, $w_{t}$ is the wage rate, $r_{t}$ is the interest rate on debt, $\tau_{t}$ is the corporate tax rate, $D_{t}$ is depreciation, and $F\left(K_{t}, L_{t}\right)$ is the production function ${ }^{7}$. The expression $\tau_{t}\left(D_{t}+r_{t} B_{t-1}\right)$ in Eq. (2) gives the tax shield from debt and depreciation. The function $A\left(B_{t-1} ; x_{t}\right)$ measures the agency costs of finance to the firm and other noninterest costs arising from asymmetric information. The vector $\boldsymbol{x}_{t}$ includes a set of variables that influence those costs of debt, such as those of the standard model: the firm's size, the ratio of net fixed assets (asset tangibility), the rate of growth of the firm (to proxy growth opportunities), and its operating profits ${ }^{8}$. The function $A\left(B_{t-1} ; x_{t}\right)$ thus captures the firm's total noninterest costs of debt arising from agency costs and other costs of asymmetric information. We shall assume that $A_{B}>0$ and $A_{B B}>0$ : the marginal cost of debt from those sources is positive and increasing in the stock of debt.

The maximization program for the firm is subject to the dynamic equation on capital stock and an upper bound on the total stock of $\mathrm{debt}^{9}$ :

$$
\begin{aligned}
& K_{t}=(1-\delta) K_{t-1}+I_{t} \\
& B_{t} \leq H_{t}
\end{aligned}
$$

The first-order condition on the stock of debt at time $t$ is:

$$
\beta_{t+1}\left[1+\left(1-\tau_{t}\right)\left(r_{t+1}+A_{B}\right)\right]-\beta_{t}+\mu_{t}=0
$$

where $\mu_{t}$ is the Kuhn-Tucker multiplier associated with the upper bound on debt. The complementary slackness condition yields:

$$
\mu_{t}\left(H_{t}-B_{t}\right)=0
$$

In an interior solution, the upper constraint on debt is not binding and the Kuhn-Tucker multiplier $\mu_{t}$ is equal to zero. The first-order condition (Eq. (5)) therefore becomes:

$$
\beta_{t+1}\left[1+\left(1-\tau_{t}\right)\left(r_{t+1}+A_{B}\right)\right]=\beta_{t}
$$

The comparative static effect on debt of a change in a variable $x_{t} \in \boldsymbol{x}_{t}$ is given by:

$$
\frac{\mathrm{d} B}{\mathrm{~d} x}=-\frac{A_{B x}}{A_{B B}}
$$

which is positive if $A_{B x}<0$. This implies that a variable $x_{t}$ has a positive influence on the stock of debt if an increase in the variable reduces the marginal cost of debt. It is important to note that the marginal impact of $x_{t}$ on debt is constant only if the ratio $A_{B x} / A_{B B}$ does not

\footnotetext{
7 We ignore adjustment costs of capital and personal taxation.

8 See Jaramillo et al., (1996) for an early application of an agency cost function to the objective function of the firm.

${ }^{9}$ We abstract from the non-negativity constraints on debt, dividends, and new equity issues since these would be irrelevant for our analysis.
} 
change with the variable $x_{t}$ or with the level of debt. In general, the effect of $x_{t}$ on the marginal asymmetric information cost of debt $A_{B x}$ will not be invariant to the level of $x_{t}$ or of $B_{t}$. This will thus introduce nonlinearities in the relationship between the variable $x$ and the level of debt.

When the upper constraint on debt is binding, the Kuhn-Tucker multiplier $\mu_{t}$ is positive. By totally differentiating Eq. (5), the effect of a variable $x_{t} \in \boldsymbol{x}_{t}$ on $B_{t}$ is given by:

$$
\frac{\mathrm{d} B}{\mathrm{~d} x}=-\frac{\mu_{x}+\beta_{t+1}\left(1-\tau_{t}\right) A_{B x}}{\mu_{B}+\beta_{t+1}\left(1-\tau_{t}\right) A_{B B}}
$$

In the presence of an upper constraint on debt, the variable $x_{t}$ may cease to influence debt and its impact could even experience a sign reversal. To see this, look at the expression in the numerator of Eq. (9). If $\mu_{x}+\beta_{t+1}\left(1-\tau_{t}\right) A_{B x}=0$ in a neighborhood of $B_{t}=H_{t}$, the marginal impact of $x_{t}$ on the opportunity cost of the constraint would exactly balance its net impact on the marginal asymmetric information cost of debt. If the marginal impact of $x_{t}$ on the opportunity cost of the constraint more than offsets its net impact on the marginal cost of debt, there would be a sign reversal in the relationship between $x_{t}$ and debt $^{10}$.

As an illustration of this, examine the role of the size of the firm on leverage. Assuming size has a negative effect on the marginal asymmetric information cost of debt $A_{B x}<0$, it would be predicted to have a positive influence on debt in an interior solution (Eq. (8)). By contrast, when the upper constraint on debt is binding, Eq. (9) would apply. A larger size could be associated with an increase in the opportunity cost of the constraint, since firms with a large stock of debt might be unable to borrow irrespective of their size. If this effect fully offsets the reduction in the marginal cost of debt in the numerator of Eq. (9), size would cease to have a positive effect on leverage at high values of the debt ratio. For sufficiently large increases in the opportunity cost of the constraint, size could have a negative effect on debt for high values of the debt ratio.

\section{Empirical method}

We test the implications of our model using the conditional quantile regression estimator developed by Koenker and Basset (1978). Conditional quantile regression traces the entire distribution of leverage, conditional on a set of explanatory variables. An overview of the distribution of firms at different levels of financial leverage can be a very informative descriptive device, especially when data are heterogeneous. Furthermore, since our sample contains large outliers and the distribution of the disturbances is nonnormal, applying conditional mean estimators to our equation would not be suitable since these estimators are not robust to departures from normality or long tail error distributions and therefore OLS is likely to produce inefficient and biased estimates. By

\footnotetext{
${ }^{10}$ More precisely, when $A_{B x}<0$ there will be a sign reversal when $\mu_{B}>0$ and $\mu_{x}>\beta_{t+1}\left(1-\tau_{t}\right)\left|A_{B x}\right|$, and when $A_{B x}>0$ there will be a sign reversal when $\mu_{B}>0$ and $\left|\mu_{x}\right|>\beta_{t^{+} 1}\left(1-\tau_{t}\right) A_{B x}$.
} 
contrast, quantile regression is robust to departures from normality and skewed tails (Mata and Machado, 1996). ${ }^{11}$

Let $\left(y_{i}, x_{i}\right), i=1, \ldots, n$ be a sample from some population where $x_{i}$ is a $(K \times 1)$ vector of regressors. Assuming that the $\theta$ th quantile of the conditional distribution of $y_{i}$ is linear in $x_{i}$, we can write the conditional quantile regression model as follows:

$$
\begin{aligned}
& y_{i}=x_{i}^{\prime} \alpha_{\theta}+u_{\theta i} \\
& \text { Quant }_{\theta}\left(y_{i} \mid x_{i}\right) \equiv \inf \left\{y: F_{i}(y \mid x) \theta\right\}=x_{i}{ }^{\prime} \alpha_{\theta} \\
& \text { Quant }_{\theta}\left(u_{\theta i} \mid x_{i}\right)=0
\end{aligned}
$$

where Quant $\theta_{\theta}\left(y_{i} \mid x_{i}\right)$ denotes the $\theta$ th conditional quantile of $y_{i}$ on the regressor vector $x_{i}$; $\alpha_{\theta}$ is the unknown vectors of parameters to be estimated for different values of $\theta$ in $(0,1) ; u_{\theta}$ is the error term which is assumed to have a continuously differentiable c.d.f. $F_{u \theta}(. \mid x)$ and a density function $f_{u \theta}(. \mid x) . F_{i}(. \mid x)$ denotes the conditional distribution function of $y$. By varying the value of $\theta$ from 0 to 1 , we trace the entire distribution of $y$ conditional on $x$.

The estimator for $\alpha_{\theta}$ is obtained from:

$$
\min \sum_{i}^{n} \rho_{\theta}\left(y_{i}-x_{i}^{\prime} \alpha_{\theta}\right)
$$

where $\rho_{\theta}(u)$ is the "check function" defined as

$$
\rho_{\theta}(u)= \begin{cases}\theta u & \text { if } u \geq 0 \\ (\theta-1) u & \text { if } u<0\end{cases}
$$

The estimator does not have an explicit form, but the resulting minimization problem can be solved by linear programming techniques (Koenker and Basset, 1978). ${ }^{12}$

Two general approaches exist for the estimation of the covariance matrix of the regression parameter vector. The first derives the asymptotic standard error of the estimator while the second uses bootstrap methods to compute these standard errors and construct confidence intervals. $^{13}$ In this paper, we employ the design matrix bootstrap method to obtain estimates of the standard errors for the coefficients in quantile regression (Buchinsky, 1995, 1998). Based on a Monte Carlo study, Buchinsky (1995) recommends the use of this method as it performs well for relatively small samples and is robust to changes of the bootstrap sample size relative to the data sample size. ${ }^{14}$ More importantly, the design

11 Robust regression analysis could also be used to address this problem. However, robust regression analysis does not allow us to estimate the coefficients for different quantiles, which is one of the objectives of this paper.

${ }^{12}$ In this study, the minimisation problem is solved by the linear programming techniques suggested by Amstrong et al., (1979).

13 Although the literature is not definite as to the 'best' path to follow, this does not pose a serious problem. As noted by Koenker and Hallock (2001), the differences between competing methods of inference for quantile regression are very small in practice and are more robust than other forms of inference in econometrics.

14 The design matrix bootstrap method amounts to sampling pairs $\left(y_{i}^{*}, x_{i}^{*}\right) i=1, \ldots, n$ at random from the original observations with replacement and recomputing the least square estimator $\hat{\alpha}^{*}{ }_{\theta}$ for each sample. Repeating this process B times yields a sample of B $p$-vectors whose sample covariance matrix constitutes a valid estimator of the covariance matrix of the original estimator. The number of bootstrap replications should be large enough to guarantee a small sample variability of the covariance matrix. In this paper, we use 1000 bootstrap replications to obtain the standard errors. 
matrix bootstrap method is valid under many forms of heterogeneity. ${ }^{15}$ In addition to the design matrix bootstrap method, we use the percentile method (Koenker and Hallock, 2001) that enables us to construct confidence intervals for each parameter in $\alpha_{\theta}$, where the intervals are computed from the empirical distribution of the sample of the bootstrapped $\hat{\alpha}^{*}{ }_{\theta} \mathrm{s} .{ }^{16}$ Unlike the standard asymptotic confidence intervals, the bootstrap percentile intervals will not generally be symmetric around the underlying parameter estimate, which is highly useful when the true sampling distribution is not symmetric. It is important to note that these bootstrap procedures can be extended to deal with the joint distribution of various quantile regression estimators, allowing us to test for the equality of slope parameters across various quantiles (Koenker and Hallock, 2001).

\section{Data, sample and empirical specification}

Sample firms are identified from Thomson Datastream and cover the 10-year period from 1992 to 2001. All the selected firms are incorporated in Korea and listed on the Korean Stock Exchange. First, we exclude firms without a complete record for all years covering a set of accounting items-including long-term debt, gross and net fixed assets, sales, and operating profits - that are required for the construction of variables to proxy the hypothesized determinants of capital structure. Second, we exclude from the sample all financial firms and regulated utilities (water, gas, and electricity). Financial firms are excluded because the nature of their liabilities and capital structure is intrinsically different from those of nonfinancial firms. Regulated utilities are excluded because of the possible effect of regulation on leverage. Firms with negative capital ratios are also excluded from the sample. We finally exclude firms with fewer than three consecutive observations. This procedure yields a sample of 4832 firm observations.

Empirical evidence on the standard model from many countries suggests that size, asset tangibility, growth, profitability, and nondebt tax shields are the main determinants of a firm's capital structure. The first four variables can be interpreted as proxies for agency costs and other costs arising from asymmetric information on the following grounds.

Bigger firms could have easier access to capital markets and borrow at more favorable interest rates, perhaps because they are more diversified in their investments and therefore have a lower risk of default than smaller firms (Ferri and Jones, 1979; Smith and Watts, 1992). This suggests a positive relationship between firm size and leverage.

Firms with large proportions of tangible assets are likely to face low costs of debt because the presence of collateralizable assets reduces the scope for asset substitution (Titman and Wessels, 1988; Harris and Raviv, 1991). In addition, tangible assets can serve as collateral against external loans (Scott, 1977). Furthermore, firms with higher liquidation value (e.g. with more tangible assets) will have higher debt since higher liquidation value makes it more likely that liquidation would be the best strategy (Harris and Raviv,

\footnotetext{
15 The design bootstrap matrix performs very well (better than the other methods considered in Buchinsky's paper) even when the errors are homoskedastic.

${ }^{16}$ See Buchinsky (1998) for a detailed description of the percentile method.
} 
1991). Thus, we expect asset tangibility to have a positive impact on the observed debt ratio by reducing the marginal agency cost of debt.

In contrast, growth opportunities represent noncollateralizable assets. Firms with a high proportion of noncollateralizable assets (such as growth opportunities or intangible assets) could find it more difficult to obtain credit because of the asset substitution effect (Bradley et al., 1984; Titman and Wessels, 1988). Furthermore, some studies have suggested that due to imperfect information regarding the behavior of firms, those firms with low tangible assets may find it difficult to raise funds via debt financing (Scott, 1977). ${ }^{17}$ Either way, firms with important growth opportunities have a higher agency cost of debt.

The pecking order hypothesis suggests a negative relationship between profitability and leverage because firms prefer to rely first on internally generated funds for the financing of their investments. When such funds are not sufficient to finance their investment, firms will resort to debt rather than equity financing. This behavior can be explained by the high costs associated with issuing new equity in the presence of asymmetric information (Myers and Majluf, 1984). Hence, a firm's profitability through its effect on the amount of retained earnings is an important determinant of its capital structure. Other things being equal, firms with more retained earnings are less inclined to resort to external debt and hence will have lower debt in their capital structure.

Various theories examine the impact of taxes on the capital structure choice of firms. In a model that incorporates corporate taxes, personal taxes, and nondebt tax shields such as depreciation allowances, DeAngelo and Masulis (1980) show that tax deductions for depreciation act as a substitute for the tax benefits associated with higher debt. Thus, firms with large nondebt tax shields should include less debt in their capital structure.

We also include time dummies to control for factors that have the same effect for all firms within a quantile at a given point in time, but vary across time. These time-specific effects include macroeconomic variables such as the price level and risk-free competitive interest rates, a financial sector crisis that induces a credit crunch, or government policies towards industrial structure or the financial system that have wide effects. In the context of Korea, time dummies may identify the effects of the economy wide shock of the 1997 crisis and of the policy and other structural changes it induced.

Based on the above discussion, we specify the following panel data model:

$$
\text { Quant }_{\theta}\left(y_{i t} \mid x_{i t}\right)=\alpha_{o}+\alpha_{\theta}^{\prime} x_{i t}+\gamma^{\prime} z_{t}
$$

where $y_{i t}$ is the dependent variable at quantile $\theta$. We use two variables to measure leverage. These are the ratio of long-term debt to total capital (LEV1) and the ratio of total-debt to total capital (LEV2). Data limitations confine us to measure debt only in book value. We use two indicators to measure a firm's size. These are the logarithm of total sales (SIZE1) and the logarithm of the total assets (SIZE2). To measure a firm's profitability (PROF), we use the earnings of a company before total interest expense, depreciation, amortization, and provisions (EBITDA) divided by total assets. Tangibility (TANG) is measured by the ratio of net fixed assets to total assets. To measure growth opportunities, we use the annual growth of

\footnotetext{
${ }^{17}$ Growth opportunities can be thought of as real options. Given the agency costs associated with these options, it is more difficult for a firm to borrow against them than against tangible fixed assets (Myers, 1977).
} 
Table 2

Correlation matrix of the variables

\begin{tabular}{|c|c|c|c|c|c|c|c|c|c|}
\hline & LEV1 & LEV2 & SIZE1 & SIZE2 & PROF & TANG & DEP & GRO1 & $\mathrm{GRO} 2$ \\
\hline LEV1 & 1.00 & & & & & & & & \\
\hline LEV2 & 0.807 & 1.00 & & & & & & & \\
\hline SIZE1 & 0.021 & 0.013 & 1.00 & & & & & & \\
\hline SIZE2 & 0.001 & 0.004 & 0.935 & 1.00 & & & & & \\
\hline PROF & -0.24 & -0.195 & 0.048 & 0.092 & 1.00 & & & & \\
\hline TANG & 0.029 & 0.015 & 0.195 & 0.106 & -0.011 & 1.00 & & & \\
\hline DEP & -0.01 & -0.038 & 0.026 & 0.051 & 0.023 & 0.430 & 1.00 & & \\
\hline GROWTH1 & -0.05 & -0.047 & 0.198 & 0.147 & -0.002 & 0.035 & -0.059 & 1.00 & \\
\hline GROWTH2 & -0.001 & -0.007 & 0.028 & 0.043 & 0.002 & -0.014 & -0.018 & 0.221 & 1.00 \\
\hline
\end{tabular}

LEV1 is the ratio of long-term debt to total capital; LEV2 is the ratio of total debt to total capital; SIZE1 is natural logarithm of total sales, SIZE2 is natural logarithm of total assets; PROF is EBITDA divided by total assets; TANG is the ratio of net fixed assets to total Assets; DEP is the ratio of depreciation expenses to total assets; GROWTH1 is the annual growth of firm's total assets; GROWTH2 is the annual growth of firm's total sales.

the firm's total assets (GROWTH1) and annual growth of the firm's total sales (GROWTH2). The nondebt tax shield (DEP) is measured by the ratio of total depreciation to total assets. ${ }^{18}$ Table 2 presents the correlation matrix of these variables. A detailed description of these variables is provided in the Appendix.

\section{Empirical results}

Eq. (15) is estimated for different values of $\theta$ that allow us to examine the impact of explanatory variables at different points of the distribution of firms' leverage. Specifically, we estimate the coefficients at seven quantiles, namely the 5th, 10th, 25th, 50th, 75th, 90th, and 95th quantiles, using the same list of explanatory variables for each of these quantiles. ${ }^{19}$ Table 3 reports the results of estimating Eq. (15) using the ratio of total debt to capital as the dependent variable while in Fig. 3a-e, we plot the estimated coefficients against the various quantiles and show the $95 \%$ confidence interval constructed using the percentile method with 1000 bootstrap replications.

For comparison purposes, column 1 in Table 3 reports the OLS estimates. Consistent with other empirical studies, the OLS results suggest that profitability, nondebt tax shields, and growth are associated with a lower debt to capital ratio while size and asset tangibility are statistically insignificant at the conventional levels.

The OLS estimator, by focusing only on the central tendency of the distribution, does not allow for the possibility that the impact of explanatory variables can be different for highly leveraged firms. The conditional quantile estimates reported in Table 3 (columns 2

\footnotetext{
18 To avoid simultaneity, all variables except for growth measures are lagged once.

19 It is worth emphasizing that for each quantile (even the most extreme ones), all the sample observations are in play in the process of quantile fitting regression. Although each fit for each quantile is ultimately determined by only a pair of sample points, all observations in the sample are needed to select which pair of points. Thus, we use the same number of observations in each of the above quantile regressions. Notice that this approach is very different from segmenting the response variables into different subsets and then running least square regression on each of these subsets which is likely to yield inconsistent and biased estimates (Koenker and Hallock, 2001).
} 
Table 3

Regression results for debt to capital ratio, 1992-2001

\begin{tabular}{|c|c|c|c|c|c|c|c|c|}
\hline & (1) OLS & (2) 5th Quant & (3) 10th Quant & (4) 25 th Quant & (5) 50th Quant & (6) 75 th Quant & (7) 90th Quant & (8) 95th Quant \\
\hline SIZE1 & $0.011(0.007)$ & $0.023(0.003)$ & $0.035(0.002)$ & $0.044(0.001)$ & $0.046(0.002)$ & $0.035(0.003)$ & $0.004(0.005)$ & $-0.014(0.007)$ \\
\hline PROF & $-0.505(0.268)$ & $-0.036(0.019)$ & $-0.071(0.035)$ & $-0.122(0.059)$ & $-0.118(0.037)$ & $-0.175(0.066)$ & $-0.109(0.062)$ & $-0.154(0.124)$ \\
\hline TANG & $0.019(0.106)$ & $0.068(0.018)$ & $0.100(0.017)$ & $0.108(0.023)$ & $0.177(0.023)$ & $0.196(0.030)$ & $0.204(0.047)$ & $0.273(0.079)$ \\
\hline DEP & $-2.015(0.373)$ & $-0.339(0.129)$ & $-0.362(0.134)$ & $-0.685(0.126)$ & $-1.303(0.125)$ & $-1.678(0.206)$ & $-1.600(0.241)$ & $-2.220(0.320)$ \\
\hline GROWTH1 & $-0.182(0.078)$ & $0.024(0.004)$ & $0.032(0.006)$ & $0.044(0.007)$ & $0.071(0.007)$ & $0.047(0.011)$ & $-0.031(0.019)$ & $-0.095(0.037)$ \\
\hline DUM1993 & $0.027(0.047)$ & $-0.008(0.009)$ & $-0.001(0.018)$ & $0.010(0.017)$ & $-0.007(0.014)$ & $-0.001(0.013)$ & $0.013(0.022)$ & $0.030(0.041)$ \\
\hline DUM1994 & $0.049(0.026)$ & $-0.007(0.011)$ & $-0.005(0.018)$ & $-0.006(0.020)$ & $-0.011(0.013)$ & $-0.032(0.016)$ & $0.011(0.021)$ & $0.034(0.035)$ \\
\hline DUM1996 & $0.124(0.046)$ & $0.002(0.015)$ & $0.008(0.017)$ & $-0.028(0.018)$ & $-0.020(0.015)$ & $-0.009(0.014)$ & $0.025(0.022)$ & $0.073(0.040)$ \\
\hline DUM1997 & $0.249(0.068)$ & $0.018(0.009)$ & $0.011(0.019)$ & $0.019(0.019)$ & $0.007(0.017)$ & $0.014(0.019)$ & $0.108(0.031)$ & $0.290(0.074)$ \\
\hline DUM1998 & $0.467(0.197)$ & $-0.031(0.009)$ & $-0.036(0.018)$ & $-0.053(0.018)$ & $-0.077(0.014)$ & $-0.037(0.023)$ & $0.189(0.065)$ & $0.426(0.127)$ \\
\hline DUM1999 & $0.270(0.123)$ & $-0.045(0.010)$ & $-0.068(0.016)$ & $-0.134(0.016)$ & $-0.172(0.014)$ & $-0.112(0.025)$ & $0.197(0.092)$ & $0.494(0.137)$ \\
\hline DUM2000 & $0.150(0.075)$ & $-0.062(0.010)$ & $-0.092(0.016)$ & $-0.179(0.015)$ & $-0.221(0.016)$ & $-0.156(0.026)$ & $0.146(0.065)$ & $0.374(0.149)$ \\
\hline DUM2001 & $0.129(0.084)$ & $-0.063(0.011)$ & $-0.095(0.016)$ & $-0.182(0.016)$ & $-0.231(0.016)$ & $-0.180(0.019)$ & $0.076(0.056)$ & $0.187(0.053)$ \\
\hline$F$-test time dummies & $2.01 * * *$ & $43.05 * * *$ & $22.43 * * *$ & $49.68 * * *$ & $70.91 * * *$ & $51.26 * * *$ & $20.15 * * *$ & $27.72 * * *$ \\
\hline
\end{tabular}

Bootstrapped standard errors in parentheses except for the OLS equation where figures in parentheses are robust standard errors. The bootstrap standard errors were obtained using 1000 bootstrap replications. All explanatory variables except GROWTH are lagged once. The number of observations is 4832 for OLS and all quantile regressions. Bold figures indicate significance at $5 \%$ or less.

*** Indicate significant at the $1 \%$ level. 

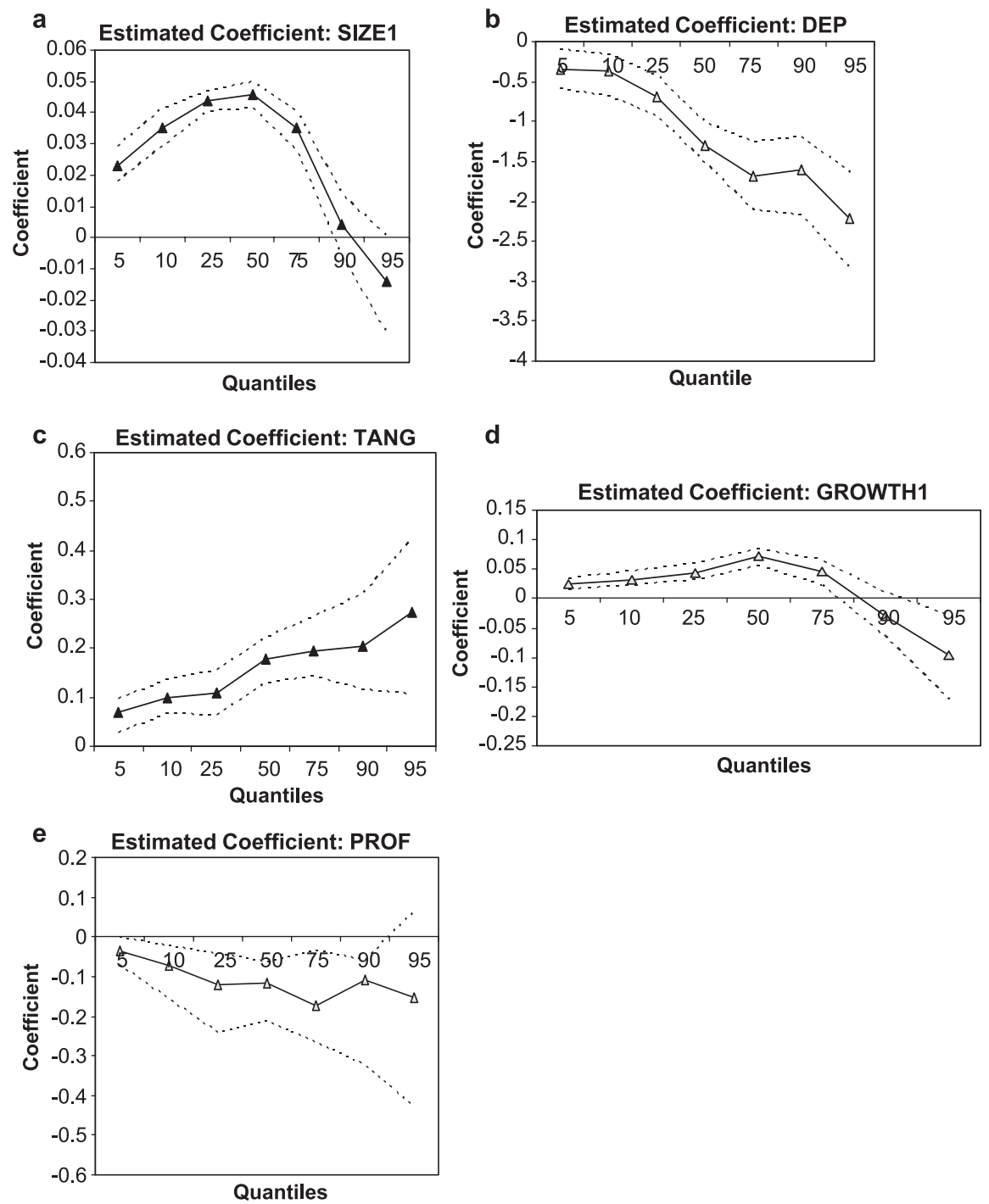

Fig. 3. (a-e) Estimated coefficients and 95\% confidence interval.

8) show that this is in fact the case and that the relationship may even change sign between quantiles. The expected different effects of the explanatory variables at the different quantiles of the distribution are reflected in the size, sign, and significance of estimated coefficients on the different variables.

Regarding the impact of size on the firm's capital structure choice, there is large variation in the magnitude and sign of the estimated coefficients as we move up the conditional distribution. While SIZE1 enters with a significantly positive coefficient at the lower quantiles, it becomes insignificant at the 90th and changes sign in the 95th quantiles, suggesting that as firms become highly leveraged, they might no longer be able to borrow 
at favorable terms regardless of their size. In terms of the model of Section 3, for high values of debt ratios, an increase in the size of the firm reduces the marginal agency cost of debt $A_{B}$, but this effect is more than offset by a large increase in the marginal opportunity cost of the constraint $\mu$ causing size to have a negative effect on debt.

The nondebt tax shield is significant in all parts of the distribution with the coefficient on DEP increasing sharply in magnitude as we move up the debt to capital distribution, suggesting that the relative advantage of resorting to debt as a tax shield alternative to depreciation is lower for high levels of leverage.

Asset tangibility (TANG) enters with a significant and positive coefficient in all parts of the distribution with the coefficient on TANG increasing in magnitude as we move up the debt to capital distribution, suggesting that the importance that lenders attach to collateral increases as leverage increases.

Growth enters with a positive and significant coefficient at low and moderate levels of leverage, but becomes insignificant at the two highest quantiles of the distribution. This may occur because at low and medium levels of leverage the asset substitution effect is low but at higher levels the marginal agency costs associated with noncollaterizable assets increase, acting as a disincentive to leverage.

As expected, PROF enters with a negative and significant coefficient, but loses significance at the 95th quantile. The bootstrapped confidence intervals, however, are quite broad at the 95th quantile and therefore we cannot base strong conclusions on the estimated coefficient.

The estimated coefficients on time dummies suggest significant effects of macrovariables that vary over time ${ }^{20}$. From 1992 to 1997 time dummies had almost no significant effect on the relation in individual quantiles, but the 1998 time dummy had a significant effect in the majority of quantiles and was significant across almost all quantiles in 1999, 2000, and 2001. These findings are consistent with the notion that the industrial and financial restructuring policies the Republic of Korea adopted after the 1997 crisis did achieve, in conjunction with other time-varying factors such as the credit crunch experienced in 1998 as a result of the financial crisis (Borenzstein and Lee, 2000), a widespread shift in the relationship between firms' financing and their agency and other asymmetric information costs.

The bootstrap procedure is extended to construct a joint distribution allowing us to devise $F$-statistics to test for the equality of the estimated coefficients across various pairs of quantiles. ${ }^{21}$ Table 4 reports the $F$-tests and the associated $p$-values for the equality of quantile slope coefficients across the various pairs of quantiles. These tests are based on the bootstrapped standard errors using 1000 replications. The tests confirm the visual inspection. The $F$-tests reject the null hypothesis of homogeneous coefficients at the $1 \%$ significance level for all pairs of quantiles, indicating that the impact of the explanatory variables is different across the different parts of the distribution.

To test the robustness of our results, we performed the following regressions. First, we included industry dummies to control for industry specific effects. Each industry may have specific features that affect the debt structure of firms in that industry. These may arise-

\footnotetext{
20 Assuming equal effects on firms within each quantile.

21 See Arias et al., (2001) for a similar application.
} 
Table 4

Debt-capital ratio: tests for equality of coefficients across quantiles

\begin{tabular}{|c|c|c|c|c|c|c|}
\hline & 5th Quant & 10th Quant & 25th Quant & 50th Quant & 75th Quant & 90th Quant \\
\hline \multicolumn{7}{|l|}{ 5th Quant } \\
\hline 10th Quant & $\begin{array}{l}F \text {-test }=4.79 \\
p \text {-val }=0.00\end{array}$ & & & & & \\
\hline 25th Quant & $\begin{array}{l}F \text {-test }=8.80 \\
p \text {-val }=0.00\end{array}$ & $\begin{array}{l}F \text {-test }=3.86 \\
p \text {-val }=0.00\end{array}$ & & & & \\
\hline 50th Quant & $\begin{array}{l}F \text {-test }=16.98 \\
p \text {-val }=0.00\end{array}$ & $\begin{array}{l}F \text {-test }=13.28 \\
p \text {-val }=0.00\end{array}$ & $\begin{array}{l}F \text {-test }=8.97 \\
p \text {-val }=0.02\end{array}$ & & & \\
\hline 75th Quant & $\begin{array}{l}F \text {-test }=8.13 \\
p \text {-val }=0.00\end{array}$ & $\begin{array}{l}F \text {-test }=7.29 \\
p \text {-val }=0.00\end{array}$ & $\begin{array}{l}F \text {-test }=6.75 \\
p \text {-val }=0.00\end{array}$ & $\begin{array}{l}F \text {-test }=5.38 \\
p \text {-val }=0.00\end{array}$ & & \\
\hline 90th Quant & $\begin{array}{l}F \text {-test }=8.15 \\
p \text {-val }=0.00\end{array}$ & $\begin{array}{l}F \text {-test }=10.16 \\
p \text {-val }=0.00\end{array}$ & $\begin{array}{l}F \text {-test }=13.94 \\
p \text {-val }=0.00\end{array}$ & $\begin{array}{l}F \text {-test }=15.59 \\
p \text {-val }=0.00\end{array}$ & $\begin{array}{l}F \text {-test }=12.43 \\
p \text {-val }=0.00\end{array}$ & \\
\hline 95th Quant & $\begin{array}{l}F \text {-test }=10.31 \\
p \text {-val }=0.00\end{array}$ & $\begin{array}{l}F \text {-test }=12.26 \\
p \text {-val }=0.00\end{array}$ & $\begin{array}{l}F \text {-test }=14.29 \\
p \text {-val }=0.00\end{array}$ & $\begin{array}{l}F \text {-test }=13.53 \\
p \text {-val }=0.00\end{array}$ & $\begin{array}{l}F \text {-test }=10.48 \\
p \text {-val }=0.00\end{array}$ & $\begin{array}{l}F \text {-test }=3.09 \\
p \text {-val }=0.00\end{array}$ \\
\hline
\end{tabular}

This table presents $F$-tests of equality of the slope coefficients (SIZEI, PROF, TANG, DEP, and GROWTH1) across quantiles, controlling for time dummies and corresponding to Table 3 . The $F$-tests for equality of slope coefficients and the corresponding $p$-values are based on the bootstrap method. All bootstrap simulations are based on 1000 replications.

among other factors - from the different business environments of the industries, the degree of competition in their product markets, and the skill composition of the industries' workforces. We classified the firms in the sample into 56 industry groups using the business description reported in Thomson Datastream. The results are reported in Table 5. As can be seen, the results change very little, with each of the variables following a similar pattern to that of Table 4. In Table 6, we report the results of using the ratio of total debt to capital as a dependent variable (LEV2). As can be seen from this table, the results are very

Table 5

Regression results for debt to capital ratio, 1992-2001 (with industry dummies)

\begin{tabular}{|c|c|c|c|c|c|c|c|c|}
\hline & $\begin{array}{l}(1) \\
\text { OLS }\end{array}$ & $\begin{array}{l}\text { (2) 5th } \\
\text { Quant }\end{array}$ & $\begin{array}{l}\text { (3) 10th } \\
\text { Quant }\end{array}$ & $\begin{array}{l}\text { (4) } 25 \text { th } \\
\text { Quant }\end{array}$ & $\begin{array}{l}\text { (5) } 50 \text { th } \\
\text { Quant }\end{array}$ & $\begin{array}{l}\text { (6) } 75 \text { th } \\
\text { Quant }\end{array}$ & $\begin{array}{l}\text { (7) 90th } \\
\text { Quant }\end{array}$ & $\begin{array}{l}\text { (8) 95th } \\
\text { Quant }\end{array}$ \\
\hline SIZE1 & $\begin{array}{l}-0.004 \\
(0.013)\end{array}$ & $\begin{array}{l}0.030 \\
(0.003)\end{array}$ & $\begin{array}{l}0.041 \\
(0.002)\end{array}$ & $\begin{array}{l}0.047 \\
(0.002)\end{array}$ & $\begin{array}{l}0.046 \\
(0.002)\end{array}$ & $\begin{array}{l}0.032 \\
(0.003)\end{array}$ & $\begin{array}{l}-0.002 \\
(0.006)\end{array}$ & $\begin{array}{c}-0.021 \\
(0.008)\end{array}$ \\
\hline PROF & $\begin{array}{c}-0.462 \\
(0.266)\end{array}$ & $\begin{array}{l}-0.042 \\
(0.022)\end{array}$ & $\begin{array}{c}-0.063 \\
(0.025)\end{array}$ & $\begin{array}{c}-0.130 \\
(0.056)\end{array}$ & $\begin{array}{c}-0.145 \\
(0.039)\end{array}$ & $\begin{array}{c}-0.141 \\
(0.058)\end{array}$ & $\begin{array}{r}-0.115 \\
(0.067)\end{array}$ & $\begin{array}{l}-0.039 \\
(0.104)\end{array}$ \\
\hline TANG & $\begin{array}{l}-0.258 \\
(0.206)\end{array}$ & $\begin{array}{l}0.119 \\
(0.022)\end{array}$ & $\begin{array}{l}0.158 \\
(0.023)\end{array}$ & $\begin{array}{l}0.187 \\
(0.026)\end{array}$ & $\begin{array}{l}0.235 \\
(0.030)\end{array}$ & $\begin{array}{l}0.193 \\
(0.037)\end{array}$ & $\begin{array}{l}0.175 \\
(0.062)\end{array}$ & $\begin{array}{l}0.122 \\
(0.086)\end{array}$ \\
\hline DEP & $\begin{array}{c}-1.808 \\
(0.485)\end{array}$ & $\begin{array}{c}-0.309 \\
(0.144)\end{array}$ & $\begin{array}{c}-0.410 \\
(0.144)\end{array}$ & $\begin{array}{c}-0.627 \\
(0.137)\end{array}$ & $\begin{array}{l}-1.137 \\
(0.158)\end{array}$ & $\begin{array}{l}-1.139 \\
(0.233)\end{array}$ & $\begin{array}{c}-1.261 \\
(0.107)\end{array}$ & $\begin{array}{c}-1.603 \\
(0.364)\end{array}$ \\
\hline GROWTH1 & $\begin{array}{c}-0.192 \\
(0.081)\end{array}$ & $\begin{array}{l}0.031 \\
(0.005)\end{array}$ & $\begin{array}{l}0.040 \\
(0.006)\end{array}$ & $\begin{array}{l}0.042 \\
(0.008)\end{array}$ & $\begin{array}{l}0.063 \\
(0.007)\end{array}$ & $\begin{array}{l}0.038 \\
(0.010)\end{array}$ & $\begin{array}{l}-0.038 \\
(0.018)\end{array}$ & $\begin{array}{r}-0.102 \\
(0.028)\end{array}$ \\
\hline
\end{tabular}

Bootstrapped standard errors in parentheses except for the OLS equation where figures in parentheses are robust standard errors. The bootstrap standard errors were obtained using 1000 bootstrap replications. All explanatory variables except GROWTH are lagged once. The number of observations is 4832 for OLS and all quantile regressions. Regression equations include time dummies. 
Table 6

Regression results for total debt to capital ratio, 1992-2001

\begin{tabular}{|c|c|c|c|c|c|c|c|c|}
\hline & $\begin{array}{l}\text { (1) } \\
\text { OLS }\end{array}$ & $\begin{array}{l}\text { (2) } 5 \text { th } \\
\text { Quant }\end{array}$ & $\begin{array}{l}\text { (3) 10th } \\
\text { Quant }\end{array}$ & $\begin{array}{l}\text { (4) } 25 \text { th } \\
\text { Quant }\end{array}$ & $\begin{array}{l}\text { (5) } 50 \text { th } \\
\text { Quant }\end{array}$ & $\begin{array}{l}\text { (6) } 75 \text { th } \\
\text { Quant }\end{array}$ & $\begin{array}{l}\text { (7) 90th } \\
\text { Quant }\end{array}$ & $\begin{array}{l}\text { (8) 95th } \\
\text { Quant }\end{array}$ \\
\hline SIZE1 & $\begin{array}{l}0.017 \\
(0.014)\end{array}$ & $\begin{array}{l}0.068 \\
(0.004)\end{array}$ & $\begin{array}{l}0.073 \\
(0.004)\end{array}$ & $\begin{array}{l}0.079 \\
(0.004)\end{array}$ & $\begin{array}{l}0.068 \\
(0.004)\end{array}$ & $\begin{array}{l}0.051 \\
(0.007)\end{array}$ & $\begin{array}{l}0.002 \\
(0.016)\end{array}$ & $\begin{array}{c}-0.075 \\
(0.027)\end{array}$ \\
\hline PROF & $\begin{array}{c}-0.758 \\
(0.329)\end{array}$ & $\begin{array}{c}-0.147 \\
(0.071)\end{array}$ & $\begin{array}{c}-0.154 \\
(0.006)\end{array}$ & $\begin{array}{c}-0.201 \\
(0.069)\end{array}$ & $\begin{array}{c}-0.186 \\
(0.005)\end{array}$ & $\begin{array}{c}-0.218 \\
(0.113)\end{array}$ & $\begin{array}{l}-0.272 \\
(0.229)\end{array}$ & $\begin{array}{l}-0.520 \\
(0.364)\end{array}$ \\
\hline TANG & $\begin{array}{l}0.085 \\
(0.240)\end{array}$ & $\begin{array}{l}0.173 \\
(0.052)\end{array}$ & $\begin{array}{l}0.185 \\
(0.045)\end{array}$ & $\begin{array}{l}0.164 \\
(0.045)\end{array}$ & $\begin{array}{l}0.190 \\
(0.052)\end{array}$ & $\begin{array}{l}0.238 \\
(0.074)\end{array}$ & $\begin{array}{l}0.234 \\
(0.141)\end{array}$ & $\begin{array}{l}0.199 \\
(0.321)\end{array}$ \\
\hline DEP & $\begin{array}{l}-5.303 \\
(0.919)\end{array}$ & $\begin{array}{l}-1.847 \\
(0.483)\end{array}$ & $\begin{array}{l}-2.051 \\
(0.349)\end{array}$ & $\begin{array}{l}-2.690 \\
(0.272)\end{array}$ & $\begin{array}{l}-3.283 \\
(0.259)\end{array}$ & $\begin{array}{c}-3.308 \\
(0.480)\end{array}$ & $\begin{array}{l}-4.769 \\
(0.632)\end{array}$ & $\begin{array}{l}-6.512 \\
(1.180)\end{array}$ \\
\hline GROWTH1 & $\begin{array}{c}-0.318 \\
(0.141)\end{array}$ & $\begin{array}{l}0.076 \\
(0.016)\end{array}$ & $\begin{array}{l}0.088 \\
(0.014)\end{array}$ & $\begin{array}{l}0.106 \\
(0.014)\end{array}$ & $\begin{array}{l}0.091 \\
(0.016)\end{array}$ & $\begin{array}{l}0.054 \\
(0.025)\end{array}$ & $\begin{array}{l}-0.085 \\
(0.049)\end{array}$ & $\begin{array}{c}-0.346 \\
(0.075)\end{array}$ \\
\hline $\begin{array}{l}F \text {-test for } \\
\text { time } \\
\text { dummies }\end{array}$ & $4.85^{* * *}$ & $26.92 * * *$ & $59.04 * * *$ & $60.18 * * *$ & $45.60 * * *$ & $25.46^{* * *}$ & $19.92 * * *$ & $9.90 * * *$ \\
\hline
\end{tabular}

Bootstrapped standard errors in parentheses except for the OLS equation where figures in parentheses are robust standard errors. The bootstrap standard errors were obtained using 1000 bootstrap replications. All explanatory variables except GROWTH are lagged once. The number of observations is 4832 for OLS and all quantile regressions. Regression equations include time dummies.

similar to those using LEV1 with the coefficients being generally higher but following a similar pattern. ${ }^{22}$

\section{Conclusions}

This paper analyzes the capital structure of listed firms in South Korea from 1992 to 2001. This issue has attracted considerable interest because of the high average debt ratios of South Korean corporations in the 1990s.

The study uses conditional quantile regression methods to explore the changing distribution of debt ratios across firms and over time. We find that variables conforming to a standard asymmetric information cost model of firms' capital structure choice have a systematic relation with capital structure in all quantiles. To that extent, the results suggest that institutional specificity of South Korea did not negate the relationship between capital structure and its determinants that have been found for other countries. However, the effect of information cost variables differs significantly between firms in different quantiles. It is noteworthy that effect changes sign in some cases. These results differ from those obtained in OLS estimates since the quantile regression method enables use to be made of greater information from the sample distribution. The nonlinearity reported including change of sign

\footnotetext{
${ }^{22}$ We also used various measures of tangibility, size, growth, and profitability. We used the following alternative measures: the ratio of gross fixed assets divided by total assets (tangibility); the logarithm of total assets as measure of size (SIZE2); the ratio of operating profit to total assets (profitability); and the percentage change of sales over 1 year (GROWTH2). The regression results are very similar to those obtained in Table 3. For space considerations, we do not report all the results. These are available from the authors upon request.
} 
is consistent with a simple model of a firm's maximization program subject to an upper bound on debt.

The results suggest an evaluation of the Republic of Korea's policy reforms following the 1997 crisis. The correlation of high leverage with size suggests that the authorities' focus on chaebol in their attempt to reduce the economy's leverage was justified. Additionally, the estimated quantile coefficients on time dummies — which are not significant before 1997, but are significant in all quantiles after 1997-suggest that firms in almost every quantile were moved off their established 'demand function for leverage', first by the severe credit crunch of 1998, and second by policy changes designed to achieve such a structural shift.

\section{Acknowledgements}

For valuable comments, we are grateful to Philip Arestis, Luca Deidda, Giancarlo Marini, Costas Meghir, Giovanni Piersanti, Stefano Usai, Mohsin Khan, Ralph Chami, Sunil Sharma, and participants in the CRENoS/CeFiMS conference (Alghero), the IMF Institute seminar, and the African Economic Research Consortium Research Group C. The usual disclaimer applies.

\section{Appendix A. Data Appendix}

\section{Measures of leverage}

LEV1: the long-term debt to capital ratio.

LEV2: the total debt (item 1301) to capital ratio.

Long-term debt (item 321) is defined as the sum of loans repayable within 5 years, long-term loans, convertible loans, and leasing finance.

Capital is the sum of (i) total share capital and reserves (item 307) defined as the sum of total equity capital, reserves and preference capital, and (ii) total loan capital.

\section{Measures of size}

SIZE1: the logarithm of total sales (item 104) defined as sales, exports, and overseas sales minus inter-company sales and value-added taxes and other duties and taxes.

SIZE2: the logarithm of the total assets (item 392) defined as the sum of net fixed assets, total intangibles, total investments, net current assets, and other assets.

\section{Measures of profitability}

PROF: the ratio of earnings of a company before total interest expense, depreciation, amortization, and provisions (EBITDA) to total assets.

\section{Measures of tangibility}

TANG: the ratio of net fixed assets to total assets.

Net fixed assets (item 339) is defined as gross fixed assets (defined as the sum of total land and building, plant machinery and equipment, and other fixed assets) minus total depreciation where total depreciation is the depreciation of total land and building, plant machinery and equipment, and other fixed assets.

Measure of non-debt tax shield

DEP: the ratio of total depreciation (item 136) to total assets. 


\section{References}

Amstrong, R.D., Frome, E.L., Kung, D.S., 1979. Algorithm 79-01: a revised simplex algorithm for the absolute deviation curve fitting problem. Communications in Statistics. Simulation and Computation, vol. B8 (2). Marcel Dekker, New York, pp. 175-190.

Arias, O., Hallock, K.F., Sosa-Escudero, W., 2001. Individual heterogeneity in the returns to schooling: instrumental variables quantile regression using twins data. Empirical Economics 26, 7-40.

Bernanke, B.S., Campbell, J.Y., 1988. Is there a corporate debt crisis? Brookings Papers on Economic Activity 2, $83-125$.

Booth, L., Aivazian, V., Demirguc-Kunt, A., Maksimovic, V., 2001. Capital structure in developing countries. Journal of Finance LV1, 87-130.

Borenzstein, E., Lee, J.-W., 2000. Financial crisis and credit crunch in Korea: evidence from firm-level data. Working Paper WP/00/25, International Monetary Fund, Washington, DC.

Bradley, M., Jarrell, G., Kim, E., 1984. On the existence of an optimal capital structure: theory and evidence. Journal of Finance 39, 857-880.

Buchinsky, M., 1995. Estimating the asymptotic covariance matrix for quantile regression models: a Monte Carlo study. Journal of Econometrics 65, 109-154.

Buchinsky, M., 1998. Recent advances in quantile regression models: a practical guideline for empirical research. Journal of Human Resources XXXIII, 88-126.

Chang, H.-J., 1994. The Political Economy of Industrial Policy. Macmillan, London.

Claessens, S., Djankov, S., Lang, L., 1998. East Asian corporates: growth, financing and risks over the last decade. World Bank, Policy Research Working Paper 2017.

DeAngelo, H., Masulis, R.W., 1980. Optimal capital structure under corporate and personal taxation. Journal of Financial Economics 8, 3-30.

Ferri, M.G., Jones, W.H., 1979. Determinants of financial structure: a new methodological approach. Journal of Finance 34, 631-644.

Financial Supervisory Commission, 2002. Improved financial structure of domestic companies listed in Korea Stock Exchange and KOSDAQ five years after the 1997 financial crisis. Press Release, Seoul, September 10th 2002.

Harris, L., 2000. Asia's schumpeter crisis: fundamentals and financial market interaction. Journal of Interdisciplinary Economics 11, 125-138.

Harris, M., Raviv, A., 1991. The theory of capital structure. Journal of Finance 46, 297-355.

Harvey, C.R., Roper, A.H., 1999. The Asian bet. In: Harwood, A., Lita, R.E, Pomerleano, M. (Eds.), Financial Markets and Development. Brookings Institution, Washington, DC, pp. 29-115.

International Monetary Fund, 1998. Republic of Korea: Selected Issues. IMF Staff Country Report No. 98/74, International Monetary Fund, Washington DC.

Jaramillo, F., Schiantarelli, F., Weiss, A., 1996. Capital market imperfections before and after financial liberalization: an Euler equation approach to panel data for Ecuadorian firms. Journal of Development Economics 51, 367-382.

Jensen, M.C., Meckling, W., 1976. Theory of the firm: management behavior, agency costs and ownership structure. Journal of Financial Economics 3, 305-360.

Kim, S.J., Stone, M.R., 1999. Corporate Leverage, Bankruptcy, and Output Adjustment in Post-crisis East Asia. IMF Working Paper 99/143, International Monetary Fund, Washington, DC.

Koenker, R., Basset, G., 1978. Regression quantiles. Econometrica 46, 33 -50.

Koenker, R., Hallock, K.F., 2001. Quantile regression: an introduction. Journal of Economic Perspectives 15, $143-156$.

Lee, J.W, Lee, Y.S., Lee, B.S., 2000. The determination of corporate debt in Korea. Asian Economic Journal 14, $333-356$.

Mata, J., Machado, J.A.F., 1996. Firm start-up size: a conditional quantile approach. European Economic Review 40, $1305-1323$.

Myers, S.C., 1977. Determinants of corporate borrowing. Journal of Financial Economics 5, 147-175.

Myers, S.C., Majluf, N.S., 1984. Corporate financing and investment decisions when firms have information that investors do not have. Journal of Financial Economics 13, 87-221. 
Pomerleano, M., Zhang, X., 1999. Corporate fundamentals and the behavior of capital markets in Asia. In: Harwood, A., Lita, R.E., Pomerleano, M. (Eds.), Financial Markets and Development. Brookings Institution, Washington, DC, pp. 117-157.

Rajan, R.G., Zingales, L., 1995. What do we know about capital structure? Some evidence from international data. Journal of Finance 50, 1421-1460.

Scott, J., 1977. Bankruptcy, secured debt and optimal capital structure. Journal of Finance 32, 1-19.

Smith, C.W., Watts, R.L., 1992. The investment opportunity set and corporate financing, dividend and compensation policies. Journal of Financial Economics 32, 263-292.

Titman, S., Wessels, R., 1988. The determinants of capital structure choice. Journal of Finance 43, 1-19. 